\title{
The Key Success Criteria for University Students Who Are Studying While Working
}

\author{
Nurul Izzati Binti Hasnun \\ School of Quantitative Sciences \\ College of Arts and Sciences \\ Universiti Utara Malaysia \\ 06010, UUM Sintok, Kedah, Malaysia
}

\author{
Dr. Nurakmal Binti Ahmad Mustaffa \\ School of Quantitative Sciences \\ College of Arts and Sciences \\ Universiti Utara Malaysia \\ 06010, UUM Sintok, Kedah, Malaysia
}

\begin{abstract}
This research primarily seeks to identify the criteria of a successful student who is studying while working and developed a framework of guidelines on how to become a successful student for an individual who is studying while working with the criteria. A survey questionnaire collected the total data of 354 and the respondents were selected using convenience sampling. For the analysis, exploratory factor analysis (EFA) was employed to determine the correlation among the variables in a data set and provides a factor structure. The result showed that three main criteria of success student have been determined, namely as Academic Preparation, Individual Trait and Support System.
\end{abstract}

Keywords:- Part-Time Students, Studying While Working, Exploratory Factor Analysis, Criteria of Successful Students.

\section{INTRODUCTION}

Lifelong Learning is an important agenda for citizens in Malaysia to acquire knowledge and skills towards the establishment of higher-income countries. A way of lifelong learning is in line with the national education system, which not limited to the levels of preschool, primary, secondary, pre-university and beyond higher education. In addition to basic education and tertiary education country, lifelong learning is the third stage in the human development capital knowledge and higher skills in Malaysia [1]. It provides a second chance to the working class and those who are previously missed the opportunity to pursue their study in higher education to obtain higherlevel education certification.

For full-time university students, working part-time is not something new and has become a norm among them. But, studying part-time for working people is something new and still a growing phenomenon in Malaysia. Nevertheless, there has been a worldwide increase in the percentage of studying while working students over the last 30 years [2]. There are several reasons for part-time students to continue their studies and the most popular reasons are to improve their personal life (i.e. higher social status and salary) and for career progression [3]. The profile of part-time students in this context is those who are adults, mostly workers and have families. Hence, it has raised many questions from various parties about students with this profile on their commitment to fully engaged in learning and graduating in the final stage of their formal education period since they are bounded to a huge number of other responsibilities.

\section{A. Problem Statement}

The most frequently asked question either in academia or industries about students who are studying while working is the issue of balancing the commitment between studying and working at the same time. In detail, the stakeholders in academia and industries are questioning whether studying while working can affect the job performances or study of the students themselves. [4] state that those who are studying while working may experience major changes in their daily routines. Under some circumstances, some students may excel in their education despite having many obstacles or they may risk drop out of their studies or lose their jobs due to difficulty of balancing work and study obligations.

Normally, workers who opted to upgrade themselves by continuing their education while working will have to sacrifice and allocate their time appropriately. They can work in the morning and study at night or work on the weekdays and study on the weekends. In any situation, they have to balance their life, work, and study to achieve their objectives without compromising the status of their study and work. Mismanagement between work and study has several adverse effects for the working students, such as a waste of money, wasted time and neglected work, which led to bad work performances [5]. As this situation can have negative effects on a student's working job, it also can affect his/her study, like low presence to the class, lack of concentration and low grades [6]. Furthermore, students who fail to adopt flexible time between work and study have a possibility of having stress [7].

\section{B. Objective of this research}

Given all these problems, it is important to find the main criteria for university students who are studying while working. Therefore, the objective of this study is to identify the criteria of a successful student who is studying while working by using the method of Exploratory Factor Analysis (EFA). 


\section{LITERATURE REVIEW}

\section{A. The Definition of Studying While Working Students (Part-Time Students)}

According to [8], a part-time student is a nontraditional student who pursues higher education, usually after he/she reaches adulthood, while living off-campus, and has commitments related to family and/or work. Status of a part-time student who studying while working usually taking fewer semester credit courses than full-time students. [4] stated that it is normally suitable for those who want to work and study at the same time, and usually study in the evening or weekends to take classes. From the aforementioned definitions, it can be concluded that a parttime student refers to a student who is working and studying during the semester, with fewer semester credit courses. Under some circumstances, the part-time student can take the maximum semester credit course for the classes over the weekends, which should not interfere with their working hours.

\section{B. Domain and Predictors of a Success Student in Higher Education Institutions}

[9] stated the predictors of student performance can be represented in many ways in the educational and theory practices. There are many types of research and policymakers have been trying to determine the successful strategy to help student success in higher education for the particular domain and gives insight on the predictors of this specific domain. A new literacy that includes digital and media technologies have evolved, especially the literacy instruction in the library, which shown to be linked positively with the success and retention of students [10]. This is possible with technology-enabled tools that also can support the strategies learnings [11] and continuous assessments [12]. [5] stated that psychosocial factors significantly to the prediction of student success, referring to students who are capable to make a good coordination of attitudes and behaviors. This concept is similar to [13] where they suggested the entry characteristics, like gender, family background, social support and adjustment have a direct or indirect association with students' academic achievement. According to [14], low-income students may be less prepared to attend university even though there is no correlation between the amount funded and student success. The non-cognitive factors as more positive student's mindset and stronger their perseverance will lead to the highest achievement in their academic [15]. It can be concluded that four criteria such as technology, family, financial and employer can be anticipated in the element of the support system. The support system also has influences student success in the university.

\section{Criteria of Success for The Part-Time Student}

The keys success criteria are important to symbolize the characteristics of an individual who is studying while working, which should be an indicator for him/her to become a successful student in higher education. In a 2016 study, [16] found that the interventions of attitudes of learning strategies, learning style, personality, motivation, social interaction and self-management contribute to the student's success. Some theories emphasize that learning strategies, personality and motivation factors significantly influence the level of success that individuals achieve in higher education [17], [18], [19], [20]. Other researchers have also pointed out that basic knowledge and soft skills significantly contribute towards students' learning outcomes, especially when the main purpose of learning is to learn new skills and knowledge [17], [21].

The most important element for part-time students to balance student life and their work schedule is time management [4]. According to [18], time management found to has a relationship with academic achievements. In this case, poor time management will lead to poor academic performance. The most discussed criteria based on previous research are knowledge, soft skills, motivation, personality and time management. It is well understood that the strong ties of the success criteria for part-time students are knowledge, soft skills, motivation, personality and time management based on literature, hence this research considered these five criteria in this research conceptual framework. Other than these five criteria, this research also considered the element of a support system as one of the important criteria, adopting from the research about determining success criteria for students in higher learning institutions [9]. From this support system element, this research has been anticipating another four criteria, which are technology, family, financial and employer. These nine criteria are then grouped into three main constructs, namely Academic Preparation, Individual Trait and Support System and the groups are summarized in Table 1.

\begin{tabular}{|c|c|}
\hline Construct & Criteria \\
\hline Academic Preparation & Knowledge \\
\hline Individual Trait & Soft skills \\
\cline { 2 - 2 } & Motivation \\
\cline { 2 - 2 } & Personality \\
\cline { 2 - 2 } & Time Management \\
\hline Support System & Technology \\
\cline { 2 - 2 } & Family \\
\cline { 2 - 2 } & Financial \\
\cline { 2 - 2 } & Employer \\
\hline
\end{tabular}

Table 1:- Overview of group of criteria considered in this study

\section{METHODOLOGY}

The methods used in data collection and data analysis were discussed in this chapter. It is explaining the research design, sampling techniques and data collection methods were used and describes how the data was collected. To conduct this research, qualitative and quantitative research methods were used. The evaluation was carried out using three systems of the data collection techniques, literature review and questionnaires. 


\section{A. Research Design and Process}

This research is intended to develop a framework of guidelines to become a successful student for an individual who is studying while working. A mixed-method, qualitative and quantitative methods were employed in this research. This research combined qualitative and quantitative research approach whereby the ultimate purpose to develop a criterion of a successful student for an individual who is studying while working model. In order to fulfill this aim, there are two research objectives need to be achieved. The overview of the research activity is illustrated in Figure 1 as follows. There are four phases of research process involved in this research. In Phase 1, the descriptive method was used to gather the information. The experimental method used in Phase 2, Phase 3 and Phase 4 to develop the conceptual model, collect the data and analysis model.

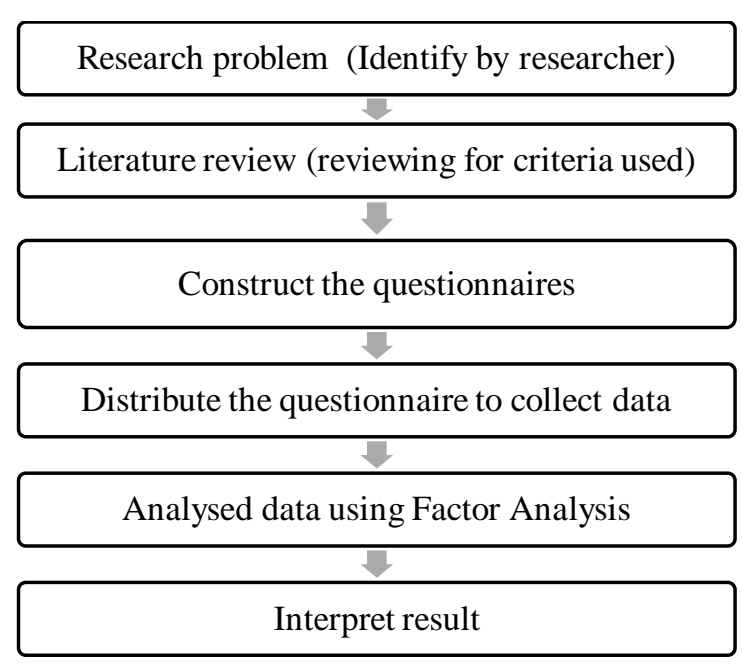

Fig 1:- Flowchart of Research Process

\section{B. Questionnaire Design}

The data for this research was collected through a questionnaire survey. A structured questionnaire was closed-ended questions and consists of four sections, covering all important aspects of demographics, three criteria of a successful part-time student, student perception about his/her academic performance and chances to retain or graduate from the formal education program. The questionnaire employed Numeric Scale and Multiple-Choice Answers. The 7-points level of importance of the numeric scale was used by presenting the respondent with an ordered set from which to choose. The scale in this questionnaire ranged from not at all important to extremely important.

\section{A Pilot Study}

A pilot study was used to evaluate the feasibility and improvement of the built questionnaire before the researcher can proceed with the data collection, whereby the data collected in this process had been analyzed to determine the questionnaire's reliability and validity. A total number of 62 experts, those who are previous part-time students had answered the questionnaire. To validate the questionnaire, face validity was used where it is a technique or procedure that looks as if it seems to be measured the variable it expected or planned to measure [22]. To establish face validity for the 47 items of the question in the questionnaire, the feedback from the experts regarding their perceptions of the relevance of those items were requested. The questionnaire distributed and answered by a few lecturers, part-time students who have graduated and senior students who working while studying.

Based on all the responses, all the 47 items were retained after the discussion on the suitable question items for the questionnaire. Then, Cronbach's coefficient alpha was calculated using the data collected to test the internal accuracy of the responses for the reliability test. The best satisfactory value of coefficient alpha is between of 0.710 and 0.999 [23]. The value of Cronbach alpha coefficient varies between 0.463 and 0.940 . In this research, all the items in the latent constructs used achieved a high-reliability coefficient, which means that the level of consistency of the questionnaire is very good and effective to use in this research.

\section{Data Collection}

The survey had been conducted after the process of checking the quality of the questionnaire. The targeted subject is a part-time university student who studying while working in the northern region of Malaysia, as the main purpose to identify the criteria of successful studying while working university students. Universiti Teknologi MARA (UITM) in Perlis, Universiti Utara Malaysia (UUM) in Kedah and Universiti Sains Malaysia (USM) in Penang was the randomly picked. A non-probability sampling, which is convenient sampling was used to collect the data. The survey questionnaire was distributed to a total of 370 respondents (total population was 9,755 part-time students of three universities), but, only 354 completed questionnaires were received. The data were collected from respondents via the online survey platform (i.e. Google Form and Email).

\section{E. Exploratory Factor Analysis}

For the analysis, the researcher uses Factor Analysis to identify the criteria of a successful student who is studying while working. Using the data collected, the variables identified in the conceptual model has been validated by running the Exploratory Factor Analysis (EFA). The EFA is a statistical technique used to determine the correlation among the variables in a data set and provides a factor structure (a grouping of variables based on high correlations). Commonly, the EFA prepares the variables to be used for cleansed structural equation modeling and should always be coordinate for new datasets.

The EFA was tested by using the Principal Components extraction method with Varimax rotation. Varimax rotation of Principal component in factor analysis attempts to discover the unexplained and unobserved factors that influence the correlated variation among multiple observations [24]. The items of the question in the questionnaire that are used to measure dependent and independent variables of the built conceptual model were included in the EFA. The results from EFA were used to confirm whether there is a need to remove the factors (or 
ISSN No:-2456-2165

items of the question) from the construct variables, which based on the remaining factors loadings as predicted onto their variables. To determine the degree of relationships between the variables, the factor loading for each variable were examined. The Kaiser-Meyer-Olkin (KMO) value, Bartlett's test of Sphericity value, factor loadings, eigenvalues, scree plot and rotated component matrix were identified in this method. According to [25], the values of KMO nearest to 1 are better and 0.6 is the minimum value. The EFA has been analyzed by using Statistical Package for Social Sciences Programme (SPSS).

\section{DATA ANALYSIS AND FINDINGS}

In this section, the findings obtained from the analyses of several tests are presented. Firstly, the profile of the respondents will be presented at the beginning of this section. Then, next the results from the Exploratory Factor Analysis will be discussed.

\section{A. Demographics Analysis}

The respondent's demographic part is presented, covering gender, age, university, mode of study, current CGPA and expected GPA of respondents. Approximately $39 \%$ (216) of the respondents were female and 61\% (138) were female. Most of the part-time student comes from UUM (66.1\%) followed by USM Penang (18.9) and at least from UiTM Perlis (15.0). About 53.7\% (190) of respondents were in the age group below 25 and $30.2 \%$ (107) were in the age group between the ages of $26-30$. Because the respondents for this research were part-time working students, in the age group of 41-55 years there were $2.5 \%$ (9) of the respondents. Of the 354 respondents, about $160(45.2 \%)$ part-time students were enrolled in postgraduate and $83(23.4 \%)$ Ph.D. part-time students. From the current CGPA of students, $75.4 \%$ (267) of parttime students have CGPA between $3.67-4.00$ and $81 \%$ (22.9) students have CGPA between 3.00 - 3.66. Besides that, it is found that $86.4 \%$ (306) of part-time students have expected GPA between $3.67-4.00$ and $13.6 \%$ (48) students have expected GPA between 3.00 - 3.66. The descriptive statistics of the respondents' demographic were tabulated in Table 2.

\begin{tabular}{|c|c|c|}
\hline Demographic & Frequency & Percentage \\
\hline \multicolumn{3}{|c|}{ Gender } \\
\hline Male & 138 & 39 \\
\hline Female & 216 & 61 \\
\hline Total Gender & 354 & 100 \\
\hline \multicolumn{3}{|c|}{ Age } \\
\hline$<25$ years old & 190 & 53.7 \\
\hline $26-30$ years old & 107 & 30.2 \\
\hline 31 - 35 years old & 37 & 10.5 \\
\hline $36-40$ years old & 11 & 3.1 \\
\hline $41-45$ years old & 5 & 1.4 \\
\hline 46 - 50 years old & 3 & 0.8 \\
\hline $51-55$ years old & 1 & 0.3 \\
\hline
\end{tabular}

\begin{tabular}{|c|c|c|}
\hline Total Age & 354 & 100 \\
\hline \multicolumn{3}{|c|}{ University } \\
\hline UUM & 234 & 66.1 \\
\hline USM Penang & 67 & 18.9 \\
\hline UiTM Perlis & 53 & 15 \\
\hline Total University & 354 & 100 \\
\hline \multicolumn{3}{|c|}{ Mode of Study } \\
\hline Part-time Degree & 81 & 22.9 \\
\hline Part-time Diploma & 30 & 8.5 \\
\hline Part-time Master & 160 & 45.2 \\
\hline Part-time PhD & 83 & 23.4 \\
\hline Total Mode of Study & 354 & 100 \\
\hline \multicolumn{3}{|c|}{ Current CGPA } \\
\hline $2.00-2.99$ & 6 & 1.7 \\
\hline $3.00-3.66$ & 81 & 22.9 \\
\hline $3.67-4.00$ & 267 & 75.4 \\
\hline Total Current CGPA & 354 & 100 \\
\hline \multicolumn{3}{|c|}{ Expected GPA } \\
\hline $3.00-3.66$ & 48 & 13.6 \\
\hline $3.67-4.00$ & 306 & 86.4 \\
\hline Total Current GPA & 354 & 100 \\
\hline
\end{tabular}

Table 2:- Descriptive statistics of demographic

\section{B. Reliability Analysis}

The results from the reliability test are presented in Table 3. The alpha coefficient of Cronbach's ranged from 0.867 to 0.946 . In this research, all the items in the latent constructs used achieved a high-reliability coefficient $(0.937>0.9)$, which means that the level of consistency of the questionnaire is very good and effective to use in this research.

\begin{tabular}{|c|c|c|c|}
\hline \multirow[t]{2}{*}{ Constructs } & \multirow{2}{*}{$\begin{array}{l}\text { Number of } \\
\text { Items }\end{array}$} & \multicolumn{2}{|c|}{ Reliability Test } \\
\hline & & $\mathrm{N}$ & Alpha \\
\hline Overall data & 43 & 354 & .937 \\
\hline \multicolumn{4}{|c|}{ Academic Preparation } \\
\hline & 3 & 354 & .946 \\
\hline \multicolumn{4}{|c|}{ Individual Trait } \\
\hline Soft Skills & 4 & 354 & .927 \\
\hline Motivation & 5 & 354 & .906 \\
\hline Personality & 5 & 354 & .885 \\
\hline $\begin{array}{c}\text { Time } \\
\text { Management }\end{array}$ & 5 & 354 & .916 \\
\hline \multicolumn{4}{|c|}{ Support System } \\
\hline Technology & 5 & 354 & .904 \\
\hline Family & 5 & 354 & .871 \\
\hline Financial & 5 & 354 & .911 \\
\hline Employer & 6 & 354 & .909 \\
\hline
\end{tabular}

Table 3:- Result of Reliability Test

\section{Exploratory Factor Analysis (EFA)}

The analysis of Exploratory Factor Analysis (EFA) was conducted on the 43 items of the three constructs identified for the conceptual model using the tests of principal component analysis extraction and varimax 
rotation. From the EFA output analysis, three sub-analyses were examined, which are, Academic Preparation (APP), Individual Trait (IT), and Support System (SS).

To examine the appropriateness of the sample size used, based on Table 4, the results of Kaiser-Meyer-Olkin Measure of Sampling Adequacy was 0.953 and the p-value of Bartlett's Test of Sphericity is highly significant $(0.000$ $<0.05)$ which proved that the sample is good and appropriate to proceed with Factor Analysis for further analysis of the data.

\begin{tabular}{|c|c|c|}
\hline \multicolumn{2}{|c|}{$\begin{array}{r}\text { Kaiser-Meyer-Olkin Measure of } \\
\text { Sampling Adequacy. }\end{array}$} & .953 \\
\hline \multirow{2}{*}{$\begin{array}{c}\text { Bartlett's Test } \\
\text { of Sphericity }\end{array}$} & Approx. Chi-Square & 18062.036 \\
\cline { 2 - 3 } & df & 903 \\
\cline { 2 - 3 } & Sig. & .000 \\
\hline
\end{tabular}

Table 4:- KMO and Bartlett's Test

The predicted factors were also examined with the value of Eigenvalues that greater than 1. The results of factor loading analysis are tabulated in Table 5 and illustrated in Figure 2. Figure 2 explains the data point that is above the breaking point of inflection for the offset of the vertical line, which represents how many factors that need to be retained. From Table 5, a total of four (4) factors explained $73.194 \%$ of the variance in this data.

\begin{tabular}{|c|c|c|c|c|}
\hline \multirow{2}{*}{ Component } & \multicolumn{3}{|c|}{ Initial Eigenvalues } & $\begin{array}{c}\text { Rotation Sums of } \\
\text { Squared Loadings }\end{array}$ \\
\cline { 2 - 5 } & Total & $\begin{array}{c}\text { \% of } \\
\text { Variance }\end{array}$ & $\begin{array}{c}\text { Cumulati } \\
\text { ve \% }\end{array}$ & Cumulative \% \\
\hline 1 & 15.611 & 36.305 & 36.305 & 32.397 \\
\hline 2 & 12.191 & 28.350 & 64.656 & 63.548 \\
\hline 3 & 2.527 & 5.877 & 70.532 & 69.999 \\
\hline 4 & 1.145 & 2.662 & 73.194 & 73.194 \\
\hline 5 & .998 & 2.320 & 75.515 & \\
\hline 6 & .697 & 1.620 & 77.135 & \\
\hline
\end{tabular}

Table 5:- Summary of Total Variance Explained
The result from Table 5 is supported with Figure 2 where it shows the offset of the vertical line, which is before point 5 and it has extracted four (4) factors. But this research used three (3) factors because the factor of four (4) has a smaller factor loading than the other factors as shown in table 6. To access significance, the factor loadings with a value of 0.4 and above are acceptable, but the values below 0.4 should be eliminated [26].

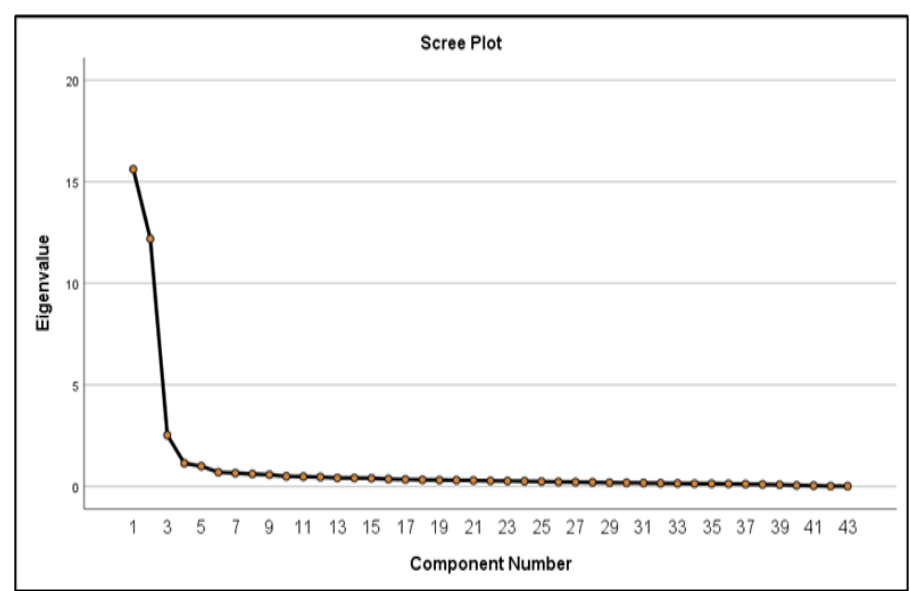

Fig 2:- Scree Plot

Table 6 shows the rotated factor loadings, which are the interaction between the variables and the factors. These are the basic factor, which has been used as the final factor after the data reduction. According to factors grouping, each group of factors is named as Support System (SS), Individual Trait (IT) and Academic Preparation (APP) to represent the factors. These statistical results support the validity and reliability of the questionnaire and signifying the goodness of fit of the data in this research.

\begin{tabular}{|c|c|c|}
\hline & Component & Factor Loadings \\
\hline \multicolumn{3}{|c|}{ CRITERIA 1: SUPPORT SYSTEM } \\
\hline \multirow{5}{*}{ TECHNOLOGY } & SS1: Enhance self-learning & 0.730 \\
\hline & $\begin{array}{l}\text { SS2: Capable to access any general computing resources at } \\
\text { the institution when I needed to }\end{array}$ & 0.910 \\
\hline & $\begin{array}{l}\text { SS3: Online additional content (e.g., research articles, links } \\
\text { to other sources) }\end{array}$ & 0.762 \\
\hline & SS4: Maximizes uses of technology and intrapersonal skills & 0.887 \\
\hline & SS5: Able to adapt to new technologies & 0.833 \\
\hline \multirow{5}{*}{ FAMILY } & SS6: Sibling's influence on academics & 0.787 \\
\hline & $\begin{array}{l}\text { SS7: Family members will encourage them to try new } \\
\text { things }\end{array}$ & 0.711 \\
\hline & SS8: Never discuss study/work issues with family & 0.805 \\
\hline & SS9: Support by home environment & 0.763 \\
\hline & $\begin{array}{l}\text { SS10: Student do not gain knowledge or skills through their } \\
\text { interaction with their family }\end{array}$ & 0.786 \\
\hline
\end{tabular}


ISSN No:-2456-2165

\begin{tabular}{|c|c|c|}
\hline \multirow{5}{*}{ FINANCIAL } & SS11: A higher level of income sufficiency & 0.747 \\
\hline & SS12: Insufficient family income & 0.791 \\
\hline & SS13: More funding opportunities & 0.801 \\
\hline & SS14: Financial aid packages and low tuition costs & 0.959 \\
\hline & SS15: Higher grant and loan amounts & 0.878 \\
\hline \multirow{7}{*}{ EMPLOYER } & $\begin{array}{l}\text { SS16: Awareness of employer about employees studying } \\
\text { part-time }\end{array}$ & 0.876 \\
\hline & $\begin{array}{c}\text { SS17: Employers' evaluations of employees' participation } \\
\text { in part-time studying }\end{array}$ & 0.739 \\
\hline & $\begin{array}{l}\text { SS18: Employers contribute towards course-related } \\
\text { expenses other than fees }\end{array}$ & 0.820 \\
\hline & SS19: More potential for promotion & 0.844 \\
\hline & SS20: Skills or knowledge specific to job roles & 0.766 \\
\hline & $\begin{array}{l}\text { SS21: Employees are asked to take on more demanding } \\
\text { tasks and responsibilities }\end{array}$ & 0.781 \\
\hline & \multicolumn{2}{|l|}{$\begin{array}{l}\text { CRITERIA 2: INDIVIDUAL TRAIT } \\
\end{array}$} \\
\hline \multirow{4}{*}{ SOFT SKILLS } & IT1: Able to manage and developing self & 0.869 \\
\hline & IT2: Working effectively with others individuals & 0.859 \\
\hline & IT3: Coping with my academic workload & 0.860 \\
\hline & IT4: Ability to analyze information & 0.859 \\
\hline \multirow{5}{*}{ MOTIVATION } & IT5: Learning to work independently & 0.841 \\
\hline & IT6: Concerned with their careers & 0.835 \\
\hline & IT7: Enjoy the social life & 0.784 \\
\hline & IT8: Wants to learn for own satisfaction & 0.845 \\
\hline & IT9: Develop a personal learning strategies plan & 0.805 \\
\hline \multirow{5}{*}{ PERSONALITY } & IT10: Have leadership qualities & 0.769 \\
\hline & IT11: Very efficiently completing assignments & 0.883 \\
\hline & IT12: Made at least one close friend at this institution & 0.703 \\
\hline & IT13: Accepting personal responsibility & 0.877 \\
\hline & IT14: Employing interdependence & 0.778 \\
\hline \multirow{5}{*}{ TIME MANAGEMENT } & $\begin{array}{l}\text { IT15: Organize deadlines for me for completing } \\
\text { work/assignments }\end{array}$ & 0.881 \\
\hline & IT16: Keep important dates on a personal calendar & 0.831 \\
\hline & IT17: Continue unprofitable routines or activities & 0.794 \\
\hline & IT18: Avoid interference in the planned schedule of study & 0.837 \\
\hline & IT19: I am controlled my own time & 0.860 \\
\hline \multicolumn{3}{|c|}{ CRITERIA 3: ACADEMIC PREPARATION } \\
\hline & $\begin{array}{c}\text { APP1: Intellectual ability } \\
\end{array}$ & 0.904 \\
\hline & $\begin{array}{c}\text { APP2: Implement more effective practices to improve } \\
\text { student outcomes }\end{array}$ & 0.912 \\
\hline & APP3: Ability to process and store information & 0.905 \\
\hline
\end{tabular}

Table 6:- Rotated Component Matrix

Extraction Method: Principal Component Analysis.

Rotation Method: Varimax with Kaiser Normalization.

Rotation converged in 5 iteration 


\section{CONCLUSION}

The primary purpose of this research was to recognize the key success criteria for university students who are studying while working in influencing the Academic Performance, Retention \& Graduation of part-time students. The findings of this research suggested the three main criteria (Support System, Individual Trait and Academic Preparation) as the key success criteria for university students who are studying while working. The findings in this research can be used as the guideline to anyone who interested in research about success students or part-time students in the higher learning institution. Thus, future part-time students can better prepare themselves in terms of their time management, career path projection and academic progression towards graduation.

With the limitations of this research, there are a few ideas that can be the recommendation for future researchers. With the use of convenience sampling, this research has been constrained only to the respondents involved. All the findings cannot be generalized to the population of studying while working (part-time) students in Malaysia. Besides that, a cause-effect relationship approach was only considered. Future research needs to investigate the two-way effects. Although some important topics could not elaborate, the objective in this research achieved. It is representing an important tool for future researchers.

\section{ACKNOWLEDGMENT}

With full commitment, finally, this research can be completed. Indeed, praise is to Allah SWT because with His permission and abundant blessings, blessings and greetings to Rasullullah S.A.W who brings grace to the whole universe. In the process of this research was conducted, I have received solid cooperation from many parties.

Foremost, I like to indicate my eternal, sincere thankful and appreciation to my supervisor, Dr. Nurakmal Binti Ahmad Mustaffa who provided so much invaluable guidance and help to complete this research. I also thank my examiner, Ts. Dr. Jastini Binti Mohd Jamil, my friends from different universities who provided good cooperation for the success of the questionnaire as well as a firm commitment to the success of this research. Without their help, this research would not be completed successfully. Also, to the fellow course mates who worked hard and helped a lot in carrying out this research. The project would never go smoothly without the inspired problem solving from them.

I would like to thanks my dear family, especially my beloved mother who really understands my demands as a student and always sends prayers of success for me. May all the services, kindness and sacrifices poured in will be rewarded by Him. Thank you very much for everyone.

\section{REFERENCES}

[1]. Ministry of Education. (2012). Malaysian Education Blueprint 2013-2025. Ministry of Education Malaysia.

[2]. Williams, J. and Kane, D. (2010). The part-time student's experience 1996-2007: An issue of identity and marginalization. Tertiary Education and Management, 16, 183-209.

[3]. Blake, J. and Worsdale, G.J. (2009). Incorporating the learning derived from part-time employment into undergraduate programmes: Experiences from a business school. Journal of Further and Higher Education, 33, 91-204.

[4]. Humayon, A.A., Raza, S., Ansari, N.u a., Fatima, A., Batool, J. and Haque, M. (2018). European Online Journal of Natural and Social Sciences, 7(1).

[5]. Krumrei-Mancuso, E. J., Newton, F.B., Kim, E. and Wilcox, D. (2013). Psychosocial Factors Predicting First-Year College Student Success. Journal of College Student Development, 54(3), 247-266.

[6]. Curtis, S. and Shani, N. (2002). The Effect of Taking Paid Employment During Term-time on Students' Academic Studies. Journal of Further and Higher Education, 26(2), 129-138.

[7]. Mitchell, J., and Soini, N. (2014). Student Involvement for Student Success: Student Staff in the Learning Commons. College \& Research Libraries, 75(4), 590-609.

[8]. Bean, J.P., and Metzner, B.S. (1985). A conceptual model of non-traditional undergraduate student attrition. Review of Educational Research, 55(4), 485540.

[9]. Zanden, P.J.V.D., Denessen, E., Cillessen, A.H. and Meijer, P.C. (2018). Domains and predictors of firstyear student success: A systematic review. Educational Research Review, 23, 57-77.

[10]. Blake, J., Bowles-Terry, M., Pearson, N.S. and Szentkiralyi, Z. (2017). The Impact of Information Literacy Instruction on Student Success: A MultiInstitutional Investigation and Analysis. Central University Libraries Research, 13.

[11]. Rodríguez, M., Mundy, M.A., Kupczynski, L. and Challoo, L. (2018). Effects of teaching strategies on student success, persistence, and perceptions of course evaluations. Research in Higher Education Journal, $35,1-21$.

[12]. Day, I.N.Z., Blankenstein, F.M.V., Westenberg, P.M. and Admiraal, W.F. (2018). Explaining individual student success using continuous assessment types and student characteristics. Higher Education Research \& Development, 37(5), 937-951.

[13]. Rodríguez, M.S., Tinajero, C. and Páramo, M.F. (2017). Pre-entry Characteristics, Perceived Social Support, Adjustment and Academic Achievement in First-Year Spanish University Students: A Path Model. The Journal of Psychology, 151(8), 722-738.

[14]. Naidoo, A. and Mckay, T. (2018). Student funding and student success: A case study of a South African university. South African Journal of Higher Education, 32(5). 
[15]. Farruggia, S.P., Han, C.-W., Watson, L., Moss, T.P. and Bottoms, B.L. (2016). Noncognitive Factors and College Student Success. Journal of College Student Retention: Research, Theory \& Practice, 20(3), 308327.

[16]. Sampelolo, R. and Atmowardoyo, H., (2016). Learning Strategies and Styles of a Part Time Job Student with Good Achievement. English Language Education, 3(1).

[17]. Koivisto, M. (2019). Work, Family and School Balanced Postgraduate Programs for Full-Time Workers in Finland. International Journal of Advanced Corporate Learning (IJAC), 12(3), 14.

[18]. Kyllonen, P.C., Lipnevich, A.A., Burrus, J. and Roberts, R.D. (2014). Personality, Motivation, and College Readiness: A Prospectus for Assessment and Development. ETS Research Report Series, 2014(1), $1-48$.

[19]. Cant, M.C., Wiid, J.A. and Machado, R. (2013). The Characteristics Of A Good ODL Practitioner. International Business \& Economics Research Journal (IBER), 12(11), 1317-1330.

[20]. Maccann, C., Fogarty, G.J. and Roberts, R.D. (2012). Strategies for success in education: Time management is more important for part-time than full-time community college students. Learning and Individual Differences, 22(5), 618-623.

[21]. Chantrea, B., Chansophy, H. and Chantyta, H. (2017). Working and Studying at the Same Time. UC Working Paper Series, 1(2).

[22]. Hardesty, D.M. and Bearden, W.O. (2004). The use of expert judges in scale development: Implications for improving face validity of measures of unobservable constructs. Journal of Business Research, 57(2), 98107.

[23]. Bond, T.G. and Fox, C.M. (2007). Applying the Rasch model: Fundamental measurement in the human sciences. (2nd ed.). Lawrence Erlbaum Associates, Publisher. Mahwah, New Jersey, London.

[24]. Hall, J.A. (2017). Introduction to Accounting Information Systems. Canada: Cengage Learning, 3, 47-53.

[25]. Tabachnick, B.G. and Fidell, L.S. (2007). Using Multivariate Statistics. (5th ed.). Boston, MA: Pearson Education. Inc.

[26]. Hair, J.F.Jr., Black, W.C., Babin, B.J., Anderson, R.E. and Tatham, R.L. (2010). Multivariate data analysis, 7th Ed., Prentice-Hall, Upper Saddle River, NJ. 